
\title{
$\angle S$ Research Square \\ Exploring educational service quality and improvement priorities from the viewpoints of health sciences students using the SERVQUAL model
}

Mohammed Al-Rabia

King Abdulaziz University

Ismail Fasfous

National Guard Health Affairs, King Abdullah International Medical Research Center

Mohamed Eldigre

National Guard Health Affairs, King Abdullah International Medical Research Center

Ahmed Aldarmahi

National Guard Health Affairs, King Abdullah International Medical Research Center

Sami Alzahrani

King Abdulaziz University

Hani Atwa ( $\nabla$ doctorhani2000@yahoo.com)

Suez Canal University

\section{Research Article}

Keywords: Quality Service, Gap, SERVQUAL, Perception, Priority, Improvement

Posted Date: September 23rd, 2021

DOI: https://doi.org/10.21203/rs.3.rs-927414/v1

License: @ (i) This work is licensed under a Creative Commons Attribution 4.0 International License. Read Full License 


\section{Abstract \\ Background}

In higher education institutes, there are competitive and tussling environments to provide students with a high educational and service quality. Service quality is the key to meet or exceed student expectations. The quality of health systems, therefore; would be directly dependent on the quality of medical sciences education. In the current study, the modified SERVQUAL model was applied to assess the quality of the educational service provided at King Abdulaziz University (KAU) in Saudi Arabia.

\section{Methods}

This is a descriptive, cross-sectional study that was conducted within the Faculties of Medicine, Applied Medical Sciences, Dentistry, and Pharmacy. Through applying the modified SERVQUAL model, the gap between students' perceptions and expectations was calculated and correlated with other demographic data. The ratio of students' perception to their expectation was calculated as a probe of student satisfaction in the current educational services to enable prioritizing items for improvement.

\section{Results}

The response rate was $89 \%(n=266)$. Out of the 266 participants, $87 \%$ were females and $13 \%$ were males. Comparisons between the gap values of male and female students showed a significant difference in the assurance and responsiveness dimensions of the educational service quality at KAU. The results showed that all items have negative gap values (except item 24). The findings showed a significant difference of students' opinion in SERVQUAL dimensions among different Faculties except in empathy.

\section{Conclusion}

The findings of this study showed that all dimensions were not up to the expectations of students. Reliability dimension and its items should be given the highest priority for improvement based on gap, ratio, and service improved matrix. The findings of this study will be very useful for the higher management to design the University Strategic Plan with well-defined direction and priorities for the improvement processes based on SERVQUAL outcomes.

\section{Introduction}

In higher education institutes, there are highly competitive and tussling environments to provide a highly valued educational and service quality [1]. Recently, higher education is dealing with high pressure to improve their quality and service, and to focus on stakeholder interests, and to improve student satisfaction [2]. The evaluation of higher education quality and service is essential to enhance educational value, to meet student satisfaction, and to give feedback on the effectiveness of educational plans and applications [3]. Service quality is the key to meet or exceed student expectations [4]. Many studies have been developed to measure student and stakeholder 
satisfaction [5]. Several tools and models have been developed to measure the quality services [6-8]. The SERVQUAL is a multidimensional model that has been widely used to measure quality services in many contexts, including service industries such as hospitality [9], banking [10], hospitals [11], mobile industry [12], and tourism [13]. In education, the model has been applied to business schools [14], and higher education institutions [4, 1517].

The SERVQUAL quality management framework, which is developed by a group of American researchers [18] in 1985 is the most common method to measure quality in the service sector. The SERVQUAL is an instrument that has 10 dimensions of service quality, which were presented together with a model of service quality. They are accessibility, reliability, responsiveness, competence, courtesy, communication, credibility, security, understanding/knowing the customer, and tangibles [19]. In education, modified SERVQUAL instruments have been validated and used [20-22]. It has also been used and formed to LibQUAL, which is used to measure academic library service quality [23].

Literature studies $[24,25]$ in higher education institutions revealed that students' perceived service quality is a precursor to student satisfaction. A high perception of service quality develops a positive image in the minds of students which then leads to satisfaction as well as to attract more students through word of mouth [26, 27]. Students' withdrawal from higher education institutions was primarily attributed to not meet their expectation [28]. Nowadays, educational institutions exert huge efforts to meet customers' expectations, similar to what business organizations do, but some of them still lack customer awareness among the staff, and it has become a common drawback for many institutions $[29,30]$.

The service quality gap is based on the difference between student's perceived services and their expectation as pointed out by Parasuraman [18], but the gap value does not provide a tool to prioritize which dimension or subdimension must be placed first for improvement. Prioritizing the service improvement is of high importance for educational management for efficient empowerment of human resources and financial capital. Recently, service improvement matrix has been used by several authors $[1,31]$ to prioritize which dimension in educational services should be improved first. Although there are some studies [32-35] dealing with quality services and student satisfaction in higher education institutions in the Kingdom of Saudi Arabia (KSA), an in-depth analysis of quality services with management education perspective is still needed. Herein, we focus on health science students' perception and satisfaction as health-related programs are in high demand by students in KSA compared to other programs. In this study, we employed a modified SERVQAUL model that consists of 27 items under five dimensions to a) assess the educational services in the five dimensions (reliability, empathy, assurance, responsiveness, tangibles), b) conduct quality service gap analysis on dimension and subdimension level, and c) set a guide to prioritize service improvement. This study also discussed the influence of gender, college, and GPA factors on the service quality gap and student's perception to expectation ratio as an indicator of improvement priority. The gap helps identifying the areas requires improvement and ratio prioritizes improvements on the quality dimension and subdimension levels. The findings will help the management develop action plans to improve the quality of institutions and its services, thereby achieving higher student satisfaction.

\section{Methods}


The study was conducted at the Faculty of Medicine (FOM), Faculty of Applied Medical Sciences (FAMS), Faculty of Dentistry (FOD), and Faculty of Pharmacy (FOP) of King Abdulaziz University in Saudi Arabia. The study design was descriptive, cross-sectional, survey based. The survey facilitated identification the students' perception and expectations of the educational environment at KAU.

The sample size was calculated by applying the following formula to estimate the number of the sample:

$$
n=\frac{z^{2} P(1-P)}{d^{2}}
$$

Where $\mathrm{n}$ : sample size, $\mathrm{z}$ : standard variable corresponding to $95 \%$ confidence level, $\mathrm{P}$ : anticipated population proportion, and $d$ : statistical precision. Using $95 \%$ confidence, $d=6 \%$ and $P=50 \%$ (as no prior information is available on population proportion). The estimated sample size is 266.

Study participants were handed hard copies of the survey. The SERVQUAL survey was originally adopted from Parasuraman et al [19] and modified and validated by Kebriaei and Akbari [36] and used by many studies [35-37]. A five-point Likert scale was used to measure the perception and expectation of perceived quality in five generic dimensions with 27 items: assurance (5 items), responsiveness (5 items), empathy (6 items), and reliability (7 items). The difference between students' perception and expectations was calculated to identify the gap by using the equation:

Service Quality Gap = Perception $(P)-\operatorname{Expectation~}(E)$

The gap between these two opinions was correlated with other demographic data (age, gender, and current GPA).

For perception, students were asked to rate each item of current services on a scale from 1 to 5 , where: $5=$ very good, 4 = good, 3 = moderate, 2 = poor, and 1 = very poor. For expectation, students were asked to rate how important each item is to the quality of the service on a scale from 1 to 5 , where: $5=$ very important, $4=$ important, 3 = moderate, 2 = less important, and 1 = least important. Most important is equal to the highest expectation and least important is equal to lowest expectation. Each item of SERVQUAL tool was scored from 1 to 5 , where: 1 = very poor/least important and 5 = very good/very important.

The ratio of students' perception to expectation was calculated to prioritize the improvement for dimension and as a probe of students' satisfaction in the educational services. The item or dimension with lowest P/E requires the highest priority for improvement. The ratio of P/E is defined as follows:

\section{Perception-to-Expectation Ratio $(P / E)=\frac{\text { Perception }(P)}{\text { Expectation }(E)}$}

When the mean score of perception is less than mean score of expectation, then P/E ratio is less than 1 implying that the perceived service does not fulfil students' expectation and they see it unsatisfactory, and it requires improvement. When the P/E ratio $=1.00$, it means that the mean score of perception equals expectation and the perceived service fulfils students' expectation, and they see it satisfactory and needs to be maintained to sustain its growth. When the value of $\mathrm{P} / \mathrm{E}$ is higher than 1 , that means score of the service provided is highly satisfactory 
to students. As the value of $\mathrm{P} / \mathrm{E}$ ratio approaches 1.00 , students become more satisfied with the service and improvement priority deceases and vice versa. Thus, the P/E ratio can be used to set out a quick guide for improvement priorities and can be used as a probe to evaluate students' satisfaction with the service.

The service improvement matrix was also developed as described in Chui et al study [1] to prioritize items for improvement. Briefly, a 2D-plot was generated by plotting the mean scores of perception (indicating satisfaction) versus mean scores of expectation (indicating importance) for each item (or dimension). The graph is divided into four quadrants based on overall mean scores of perception and expectation for items. The quadrant with items having mean scores of perception (satisfaction) lower than the overall mean score of perception (27 items) and mean scores of expectation (importance) higher than the overall mean score of expectation require prioritize improvement.

The data were analyzed using IBM SPSS 24.0 software (IBM Inc.). Descriptive statistics for demographic data were calculated, which include frequencies and percentages. Inferential statistics using nonparametric tests of Wilcoxon test for paired samples, Kruskal Wallis test, and Spearman correlation coefficients were conducted. The difference between students' perceptions and expectations was calculated to identify the gap between them. The perception/expectation ratio was calculated as a probe of students' satisfaction. The reliability of the survey instrument was determined by using Cronbach's alpha value and found to be 0.896 and 0.927 for perception items and expectation items, respectively. The level of significance was set at $p<0.05$.

Ethical approval was obtained from the Research Ethics Committee of the Faculty of Medicine, King Abdulaziz University

\section{Results}

Frequency distributions and percentages of student basic characteristics and demographic data are presented in Table 1. The response rate was 89\% $(n=266)$. Out of the 266 participants, $87 \%$ were females and 13\% were males. Most of the participants aged 18-23 years old. Students in the study sample were distributed among four colleges, which are FOM, FAMS, FOD, and FOP. Most of the students are in the second year (70.3\%). Most participants had Grade Point Average (GPA) equal to or greater than 4.1 out of 5 .

\section{Table 1: Basic characteristics of students included in the study $(n=266)$ :}




\begin{tabular}{lcc}
\hline Variable & Frequency & Percentage (\%) \\
\hline Gender & & \\
Male & 35 & 13.2 \\
Female & 231 & 86.8 \\
Age (in years) & & \\
18-19 & 41 & 15.4 \\
$20-21$ & 186 & 69.9 \\
$22-23$ & 32 & 12.0 \\
$24-25$ & 6 & 2.3 \\
$26+$ & 1 & 0.4 \\
Faculty & & \\
FOM & 80 & 30.1 \\
FAMS & 62 & 23.3 \\
FOP & 51 & 19.2 \\
FOD & 73 & 27.4 \\
GPA & & \\
$2.0-2.9$ & 4 & 1.5 \\
$3.0-3.5$ & 7 & 2.6 \\
$3.6-4.0$ & 35 & 13.2 \\
$4.1-4.5$ & 91 & 34.2 \\
$4.6-5.0$ & 129 & 48.5 \\
\hline
\end{tabular}

The difference between students' perception and expectation and the ratio $\mathrm{P} / \mathrm{E}$ were calculated for all items and presented in Table 2. Furthermore, the overall gap and ratio of each domain were also calculated. There was a significant difference $(p<0.00)$ between perception and expectation for all items except for item 24 (Professional appearance of faculty members and staff). Negative gap was observed for all items except for item 24 . The P/E ratio for all items was equal to or greater than 0.67 . Item 24 scored the highest $\mathrm{P} / \mathrm{E}$ ratio 1.20 , with no significant difference between perception and expectation mean values. Figure 1 shows a direct linear relationship between $\mathrm{P} / \mathrm{E}$ ratio and service quality gap $(\mathrm{P}-\mathrm{E})$ with high correlation coefficient $\left(\mathrm{R}^{2}\right.$ $=0.9412)$. As the value of the service quality gap $(\mathrm{P}-\mathrm{E})$ in educational services gets wider (more negative) the value of $\mathrm{P} / \mathrm{E}$ becomes progressively less than 1 .

Table 2: Mean scores of students' perception (P) and expectation (E), gap (P - E) and extent of satisfaction $(P / E$ ratio $)$ in 27 items and five dimensions ${ }^{\dagger}(n=266)$ : 


\begin{tabular}{|c|c|c|c|c|c|}
\hline \multirow[t]{2}{*}{ ion } & Perception & Expectation & $\begin{array}{c}P- \\
\mathrm{E}\end{array}$ & p- & $\mathrm{P} / \mathrm{E}$ \\
\hline & Mean & Mean & Gap & value & Ratio \\
\hline \multicolumn{6}{|l|}{ ice } \\
\hline itating discussion and interaction about lessons in class & 3.25 & 4.21 & -0.96 & $0.000^{*}$ & 0.84 \\
\hline fying students for future job & 3.20 & 4.56 & -1.36 & $0.000^{*}$ & 0.74 \\
\hline $\begin{array}{l}\text { ssibility of faculty members to Answer students' questions } \\
\text { the class }\end{array}$ & 3.45 & 4.29 & -0.83 & $0.000^{*}$ & 0.87 \\
\hline $\begin{array}{l}\text { essibility of adequate references to increase students' } \\
\text { ional }\end{array}$ & 3.32 & 4.17 & -0.85 & $0.000^{*}$ & 0.85 \\
\hline \multirow[t]{2}{*}{ rledge of the faculty members and its adequacy } & 3.86 & 4.55 & -0.68 & $0.000^{*}$ & 0.87 \\
\hline & 3.42 & 4.36 & -0.94 & $0.000^{*}$ & 0.83 \\
\hline \multicolumn{6}{|l|}{ siveness } \\
\hline rvisors' accessibility when needed & 3.41 & 4.15 & -0.74 & $0.000^{*}$ & 0.89 \\
\hline $\begin{array}{l}\text { accessibility of administrators to express views about the } \\
\text { um }\end{array}$ & 3.08 & 4.10 & -1.02 & $0.000^{*}$ & 0.81 \\
\hline ducing suitable references to students to read & 3.18 & 4.08 & -0.90 & $0.000^{*}$ & 0.84 \\
\hline $\begin{array}{l}\text { ing an allowance for students' views and suggestions in } \\
\text { um }\end{array}$ & 3.02 & 4.24 & -1.22 & $0.000^{*}$ & 0.76 \\
\hline \multirow{2}{*}{$\begin{array}{l}\text { laring the hours that students can refer to faculties to talk } \\
\text { their educational problems }\end{array}$} & 3.52 & 4.21 & -0.69 & $0.000^{*}$ & 0.89 \\
\hline & 3.42 & 4.36 & -0.94 & $0.000^{*}$ & 0.84 \\
\hline \multicolumn{6}{|l|}{$\mathbf{y}$} \\
\hline gning suitable and relevant homework & 3.12 & 3.75 & -0.63 & $0.000^{*}$ & 0.95 \\
\hline $\begin{array}{l}\text { ulty members flexibility when exposing to specific conditions } \\
\text { student }\end{array}$ & 3.15 & 4.27 & -1.11 & $0.000^{*}$ & 0.81 \\
\hline venience of class hours & 2.82 & 4.42 & -1.59 & $0.000^{*}$ & 0.67 \\
\hline nt and convenient places in school for reading & 3.40 & 4.38 & -0.98 & $0.000^{*}$ & 0.83 \\
\hline pectful behavior of school staff with students & 3.76 & 4.49 & -0.73 & $0.000^{*}$ & 0.86 \\
\hline \multirow[t]{2}{*}{ pectful behavior of faculty members with students } & 3.79 & 4.51 & -0.71 & $0.000^{*}$ & 0.88 \\
\hline & 3.34 & 4.30 & -0.96 & $0.000^{*}$ & 0.83 \\
\hline \multicolumn{6}{|l|}{ ity } \\
\hline senting educational content regularly and relevantly & 3.70 & 4.42 & -0.71 & $0.000^{*}$ & 0.90 \\
\hline rming students about the result of the examinations & 3.16 & 4.44 & -1.28 & $0.000^{*}$ & 0.76 \\
\hline senting materials and content understandably & 3.10 & 4.47 & -1.37 & $0.000^{*}$ & 0.76 \\
\hline higher scores if students attempt more & 2.51 & 4.11 & -1.60 & $0.000^{*}$ & 0.67 \\
\hline ording students' educational documents without mistake & 3.35 & 4.35 & -0.99 & $0.000^{*}$ & 0.81 \\
\hline y accessibility of available references at the university & 3.39 & 4.14 & -0.74 & $0.000^{*}$ & 0.87 \\
\hline \multirow{2}{*}{$\begin{array}{l}\text { filling responsibilities by faculty members and staff in the } \\
\text { ad time }\end{array}$} & 3.17 & 4.36 & -1.19 & $0.000^{*}$ & 0.76 \\
\hline & 3.20 & 4.33 & -1.13 & $0.000^{*}$ & 0.79 \\
\hline \multicolumn{6}{|l|}{ es } \\
\hline fessional appearance of faculty members and staff & 4.05 & 3.93 & 0.11 & 0.160 & $1.20^{\ddagger}$ \\
\hline tal appealing and comfort of physical facilities & 3.39 & 4.31 & -0.91 & $0.000^{*}$ & 0.88 \\
\hline to date material and educational equipment & 3.26 & 4.41 & -1.15 & $0.000^{*}$ & 0.79 \\
\hline \multirow[t]{2}{*}{ tal appealing of teaching tools } & 3.20 & 4.18 & -0.98 & $0.000^{*}$ & 0.85 \\
\hline & 3.47 & 4.21 & -0.73 & $0.000^{*}$ & 0.93 \\
\hline
\end{tabular}

cores were calculated based on individual student's crude responses. ${ }^{\ddagger} \mathrm{P} / \mathrm{E}$ ratio is higher than 1 although there is no sic e between $\mathrm{P}$ and $\mathrm{E}$ values. Overall means for 27 items: perception 3.32; expectation $=4.28$; Gap $=-0.96$; P/E ratio $=0.78{ }^{*}$ Sta nt. 
Comparing the score of overall quality gap calculated among the five quality dimensions using Wilcoxon test showed a significance difference. Table 3 summarized the results of Spearman correlation analysis between the components of service quality. Positive and significant correlations were revealed between the components. Reliability was strongly correlated with assurance and responsiveness.

Table 3: Correlation between service quality dimensions:

\begin{tabular}{lccccc}
\hline Dimension & Assurance & Responsiveness & Empathy & Reliability & Tangibles \\
\hline Assurance & 1.000 & & & & \\
Responsiveness & 0.538 & 1.000 & & & \\
Empathy & 0.300 & 0.458 & 1.000 & & \\
Reliability & 0.548 & 0.552 & 0.456 & 1.000 & \\
Tangibles & 0.222 & 0.341 & 0.323 & 0.407 & 1.000 \\
\hline
\end{tabular}

*Statistically significant

The significant difference between male and female students based on SERVQUAL dimensions was tested. It revealed that there was a significant difference in assurance and responsiveness based on gender $(p<0.05)$ as shown in Table 4 . The $\mathrm{P} / \mathrm{E}$ ratio showed significant difference in assurance, responsiveness, and empathy based on gender, indicating the difference between the gap and ratio values.

Table 4: Service quality gap and P/E ratio for five dimensions based on students' gender:

\begin{tabular}{|c|c|c|c|c|c|c|}
\hline \multirow[t]{2}{*}{ Dimension } & \multicolumn{2}{|c|}{ Gap (P - E) } & \multirow[t]{2}{*}{ p-value } & \multicolumn{2}{|c|}{ Ratio (P/E) } & \multirow[t]{2}{*}{ p-value } \\
\hline & Male & Female & & Male & Female & \\
\hline Assurance & -1.32 & -0.88 & $0.007^{*}$ & 0.72 & 0.81 & $0.015^{*}$ \\
\hline Responsiveness & -1.38 & -0.84 & $0.002^{*}$ & 0.69 & 0.82 & $0.003^{*}$ \\
\hline Empathy & -1.22 & -0.92 & 0.071 & 0.73 & 0.80 & $0.043^{*}$ \\
\hline Reli & -1 . & -1.09 & 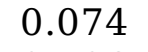 & 0.70 & 0.76 & 098 \\
\hline Tangibles & -0.80 & -0.73 & 0.706 & 0.85 & 0.87 & .750 \\
\hline
\end{tabular}

${ }^{*}$ Statistically significant

Kruskal-Wallis test was used to test whether the faculty has a significant difference with the responses of SERVQUAL dimensions or not. Table 5 showed the significant differences between students' perceptions and expectations in assurance, responsiveness, reliability, and tangibles dimensions $(p<0.05)$. On the other hand, empathy has no significant difference $(p>0.05)$. 
Further analysis to compare the faculties based on $\mathrm{P} / \mathrm{E}$ ratio was performed and results indicated a significant difference $(p<0.05)$ for the five dimensions except for empathy.

Table 5: Service quality gap and P/E ratio by students' college:

\begin{tabular}{lccccc}
\hline Dimension & \multicolumn{5}{c}{ Ratio (P/E) } \\
& FOM & FAMS & FOP & FOD & p-value \\
\hline Assurance & 0.74 & 0.79 & 0.85 & 0.83 & $0.015^{*}$ \\
Responsiveness & 0.80 & 0.73 & 0.85 & 0.83 & $0.039^{*}$ \\
Empathy & 0.83 & 0.78 & 0.77 & 0.78 & 0.406 \\
Reliability & 0.76 & 0.76 & 0.81 & 0.69 & $0.008^{*}$ \\
Tangibles & 0.94 & 0.88 & 0.83 & 0.79 & $0.019^{*}$ \\
\hline Dimension & \multicolumn{5}{c}{ Gap (P - E) } \\
& FOM & FAMS & FOP & FOD & p-value \\
\hline Assurance & -1.18 & -0.93 & -0.76 & -0.80 & $0.021^{*}$ \\
Responsiveness & -0.93 & -1.19 & -0.74 & -0.77 & $0.040^{*}$ \\
Empathy & -0.82 & -0.98 & -1.08 & -1.01 & 0.425 \\
Reliability & -1.06 & -1.08 & -0.89 & -1.40 & $0.009^{*}$ \\
Tangibles & -0.45 & -0.66 & -0.84 & -1.02 & $0.009^{*}$ \\
\hline
\end{tabular}

${ }^{*}$ Statistically significant

Kruskal-Wallis test was used to test whether the GPA has a significant difference with the responses of SERVQUAL dimensions or not. Table 6 showed significant difference between students' perceptions and expectations only in reliability dimension. Interestingly, lowest GPA range scored the largest gap and lowest student $\mathrm{P} / \mathrm{E}$ ratio.

Table 6: Service quality gap and P/E ratio by students' GPA:

\begin{tabular}{lcccccc}
\hline Dimension & \multicolumn{3}{c}{ Ratio (P/E) } & p-value \\
& $\mathbf{2 . 0 - 2 . 9}$ & $\mathbf{3 . 0 - 3 . 5}$ & $\mathbf{3 . 6 - 4 . 0}$ & $\mathbf{4 . 1 - 4 . 5}$ & $\mathbf{4 . 6 - 5 . 0}$ & \\
\hline Assurance & 0.63 & 0.79 & 0.77 & 0.79 & 0.82 & 0.231 \\
Responsiveness & 0.54 & 0.92 & 0.77 & 0.81 & 0.81 & 0.113 \\
Empathy & 0.68 & 0.78 & 0.81 & 0.79 & 0.80 & 0.855 \\
Reliability & 0.59 & 0.78 & 0.72 & 0.72 & 0.78 & $0.043^{*}$ \\
Tangibles & 0.54 & 0.93 & 0.92 & 0.81 & 0.89 & 0.059 \\
\hline Dimension & $\mathbf{c}$ Gap (P-E) & \multicolumn{3}{c}{ p-value } \\
& $\mathbf{2 . 0 - 2 . 9}$ & $\mathbf{3 . 0 - 3 . 5}$ & $\mathbf{3 . 6 - 4 . 0}$ & $\mathbf{4 . 1 - 4 . 5}$ & $\mathbf{4 . 6 - 5 . 0}$ & \\
\hline Assurance & -1.90 & -1.02 & -1.06 & -0.96 & -0.86 & 0.170 \\
Responsiveness & -2.10 & -0.43 & -1.01 & -0.85 & -0.91 & 0.070 \\
Empathy & -1.54 & -0.93 & -0.90 & -1.00 & -0.93 & 0.731 \\
Reliability & -1.96 & -0.98 & -1.21 & -1.25 & -1.00 & 0.069 \\
Tangibles & -1.93 & -0.36 & -0.63 & -0.90 & -0.63 & 0.050 \\
\hline
\end{tabular}


* Statistically significant

\section{Improvement service matrix graph was developed and presented in Figure 2. Vertical and horizontal lines represent the mean scores of perception and expectation for 27 items.}

\section{Discussion}

The results presented in Table 2 indicate that the mean scores of students' perception and expectation were significantly different for all items of services $(p<0.001)$ except for item 24 (Professional appearance of faculty members and staff). In all items, the quality gap values between students' perception and expectation are negative, indicating that students do not perceive that the actual services provided by the university meet their expectation except for item 24. The overall gap values for the five dimensions exhibit the smallest and largest gap values for "tangibles" and "reliability" dimensions, respectively. The results highlight that there are substantial areas for improvement and growth in educational services. The reliability dimension reflects the consistency of institution or program in terms of performance, as indicated in a similar study by Legčević [38]. This finding is consistent with the result reported by other studies $[5,31,39]$.

The $\mathrm{P} / \mathrm{E}$ ratio for reliability was the smallest among other dimensions, which prioritizes it as the first dimension to be tackled by decision makers to eliminate or reduce the gap value and, additionally, positively affect the quality gaps in other dimensions [30]. Conversely, other studies have shown that other quality dimensions had the greatest quality gap. Aldarmahi et al [35] employed the SERVQUAL model to assess the quality gap between student expectations and perceptions of the service quality in King Saud bin Abdulaziz University for Health Sciences in Saudi Arabia and found negative overall gap values for the five dimensions with the largest gap for responsiveness, reliability, empathy, assurance, and tangibles. A study [40] in a private university in Thailand investigated service quality using SERVQUAL model and reported a negative gap between the students' perceptions and expectations in the 5 dimensions employed. The author recommended that higher educational institution in Thailand to upgrade facilities and equipment to reduce the gap and improve service delivery.

Ten out of the 27 items had gap in quality services less than -1, which requires action plans to minimize or eliminate the gap between student perception and expectation. In reliability dimension, the largest gap was 1.60 in item 20 (Give higher scores if students attempt more), indicating that most of the students feel that their extra efforts and attempts do not necessarily lead to a better grade or score. Items 18 and 19 also identified areas for improvement in presenting the content material comprehensibly and informing students about their exam results, assignments, and homework in the assigned or promised timetable. Low student perception (satisfaction) in item 23 (Fulfilling responsibilities by faculty members and staff in the promised time) suggests that faculty and staff need additional training and attending workshops and seminars to meet students' expectation. In assurance dimension, item 2 (Qualifying students for future job) had a gap of -1.36 indicating that students do not feel that the university qualifies them for future jobs, which requires further improvement in the curriculum to include what students can do in the future rather than focusing on mere teaching of the content. This requires the university to set out clear learning outcomes from the program level to lecture level and share them with students. 
In responsiveness dimension, two items (7 and 9) had gaps less than - 1 about the curriculum and easy accessibility of administrators to receive students' suggestion and opinions. Students do not feel that their views and suggestions are taken into consideration when structuring or updating the curriculum. This also provides a room to improve the way of collecting students' feedback on the contents and teaching, learning, and assessment strategies of courses, and how this feedback is evaluated and become part of the curriculum development cycle.

In empathy dimension, two items (12 and 13) had gaps less than - 1 about flexibility of faculty members to understand students' situation under certain conditions and the convenience of class hours. The allotted time for classes was not satisfactory where the students perceived a low mean score of 2.82 (low satisfaction) while they were expecting high score of 4.45 (high importance).

The tangibles dimension has the smallest gap on quality services presented to student based on their opinions. Only one item (Up to date material and educational equipment) had a gap less than - 1, indicating the need to update the material.

The results showed a narrower service gap in educational services as reported by female students compared to male students in the five dimensions and a statistically significant difference was revealed in two dimensions: assurance and responsiveness. The perception-to-expectation ratio for female students was higher than male students in all dimensions and a significant difference was shown in three dimensions: assurance, responsiveness, and empathy. The results indicate higher satisfaction of female students on the service quality provided. Different results were reported in the literature regarding the impact of gender on service quality and students' satisfaction. Ansary et al [41] had reported no significant effect of gender on service quality measured for 250 students from different nationalities in private higher education institution in Malaysia. Ham and Hayduk [42] showed that there is no significant difference between male and females with perceived service quality even though the findings do show that males are more satisfied compared to females. Ilias et al [43] reported that there are no significant differences between male and female students with both quality service and satisfaction. Aldarmahi et al [35] had reported that there was a significant difference between male and female undergraduate students in their quality gap values in the empathy, tangibles and responsiveness dimensions in a study conducted in King Saud bin Abdulaziz University for Health Sciences in Saudi Arabia. The greatest gap (dissatisfaction) was reported for female students in responsiveness and for male students in empathy and tangibles. Soutar and McNeil [44] found that there is a significant relationship between gender and satisfaction with service quality as males are more satisfied than females. Our finding agrees with those reported by Osman et al [45] that there was a significant difference in satisfaction between male and female students with females had a higher level of satisfaction compared to males. More research efforts are necessary to understand the differences among students' experiences to improve services offered to them, which consequently lead to student satisfaction.

In comparison between the students of the four colleges, the lowest P/E ratio and gap were reported in assurance dimension for FOM students, in responsiveness dimension for FAMS students, in empathy dimension for FOP students, and in reliability dimension for FOD students. Students at different colleges respond differently to the services provided by the university. Statistically significant differences were revealed among the students of the four colleges in assurance, responsiveness, tangibles, and reliability dimensions. Empathy was the only dimension that did not show any significant differences among the various colleges' students. Yusoff et al [46]

Page $11 / 18$ 
studied the influence of the program of study and other demographic factors on dimensions driving student satisfaction factors in Malaysia and found that commerce-tourism programs and international business programs are less satisfied compared to other programs within business schools.

Students with lowest GPAs showed greatest quality gaps (more negative) in all domains, which requires taking actions to reduce that gap with this group of students. However, no statistically significant differences were detected between students with different GPAs. Furthermore, students with lowest GPA exhibited lowest P/E ratio, reflecting their low satisfaction with the provided services. Our results are consistent with those reported by Ham and Hayduk [42] and llias et al [43].

The gap can identify the areas for improvement and P/E can probe the extent of the student's satisfaction and helps university administration to set priority improvement strategy not only for the whole dimension but also for each item in the survey. Items with the lowest P/E ratios (e.g., 13 and 20) should be given priority for improvement. In the same line, the developed improvement matrix graph (Fig. 2) indicated that the items in quadrant B perceive low satisfaction compared to its mean (3.32) and high importance compared to its mean (4.28), thus they should be given priority for improvement. Quadrant $D$ items should be improved while item 24 must be maintained (perception > expectation). Quadrant A should be improved while its items present the best services in students' perception and importance. In a similar study, Chui et al [1] have developed service improvement matrix to prioritize the dimensions/items in SERVQUAL instrument for necessary and important improvement in private university in Malaysia. They found that the top priority should be directed to empathy dimension.

\section{Limitations}

The data collected in this study reflect the responses of health sciences students enrolled in four faculties during one semester. Including more faculties would have strengthened the results and improved the generalizability of the study findings. Another limitation is that our study depended only on quantitative data. Adding a qualitative component (through focus groups or structured interviews) would have consolidated the findings and added to the credibility of the study.

\section{Conclusion And Recommendations}

This study investigated gap and ratio of students' perceptions to expectations of educational service quality in four health sciences education faculties at King Abdulaziz University in Saudi Arabia by using a modified version of the SERVQUAL model. The findings of this study showed that all the dimensions were not up to the expectations of students. Improvements are needed across all five SERVQUAL dimensions. P/E Ratio and service improvement matrix can be used as a guide to determine which item/dimension should be prioritized for improvement. Gender and faculty factors tend to have a significant impact on some dimensions. The results are deemed to help the university to develop action plans to address all weaknesses. It is strongly recommended to replicate this study in other universities and in various programs. This might result in developing guidelines for the educational system improvement at the national level. In addition, future work venues may include: conducting service quality measurement at program, university, and national levels on a continuous basis to understand students' perception and expectation of current service and monitor them overtime; invoking institution self-study approach based on SERVQUAL periodically to minimize/eliminate the gaps and improves

Page 12/18 
the services; and conducting comparative studies between private and public higher educational institutions for the quality service and student satisfaction to identify the differences and capitalize on the strength points of difference.

\section{Declarations}

\section{Acknowledgements}

The authors would like to thank the students who participated in the study. Thanks also are presented to the administration of the four study faculties for providing help and support.

\section{Authors' information}

MA is a Professor of Medical Microbiology and Parasitology, Faculty of Medicine, King Abdulaziz University in Saudi Arabia. He has a master's degree in Medical Education from King Abdulaziz University in Saudi Arabia. He published more several research papers in both Medical Education and Microbiology and Immunology in peerreviewed international journals.

IF is an Associate Professor and Chairman of the Quality Assurance and Academic Accreditation Unit in the College of Science and Health Professions at King Saud bin Abdulaziz University for Health Sciences, Jeddah, Saudi Arabia. He has more than fifteen years of diverse experiences in chemistry, teaching and learning, and academic accreditation. He has more than thirty research papers in refereed journals. His current research interests include preparing new nanomaterials for environmental and health applications, method development, education, and academic accreditation.

ME is an Assistant Professor of Biostatistics, College of Science and Health Professions at King Saud bin Abdulaziz University for Health Sciences, Jeddah, Saudi Arabia. He has a PhD in biostatistics. He has special interest in teaching, learning, and assessment in the health professions. He co-authored a number of research papers in Medical Education and helped in advanced data analysis of many others.

AA is the Associate Dean and Chairman of Basic Science Department. He's also the Chairman of the Quality Assurance and Academic Accreditation, College of Science and Health Professions at King Saud bin Abdulaziz University for Health Sciences, Jeddah, Saudi Arabia. He holds a PhD and master's degree in Medical Education. $\mathrm{He}$ is an active researcher and reviewer for several journals. He organized several conferences and workshops in medical education.

SA is a consultant of Family Medicine and Head of the Family Medicine Department and Family Medicine Clinics at the Faculty of Medicine, King Abdulaziz University, Jeddah, Saudi Arabia. SA holds a master's degree in medical education. He co-authored a number of research papers both in Family Medicine and Medical Education in peer-reviewed international journals and obtained a number of research grants.

HA is an Associate Professor of Medical Education at both the College of Medicine and Medical Sciences, Arabian Gulf University, Kingdom of Bahrain and the Faculty of Medicine, Suez Canal University, Egypt. He is an MD and has a PhD in Medical Education. He has special interest in curriculum development, student assessment, and faculty development. He published several research papers in peer-reviewed international journals. He has also presented regularly at national and international conferences. 
Authors' contributions

Conceptualization: MA, IF and AA; Data curation: MA, IF, ME, AA, and SA; Data analysis, MA, IF, ME, AA, and HA; Methods: MA, SA, AA, IF and HA; Writing - original draft: MA, IF, ME, AA, SA, and HA; Writing - review and editing: MA, IF, ME, AA, SA, and HA. All authors have reviewed and approved the manuscript.

\section{Funding}

The work was self-funded by the authors.

\section{Availability of data and materials}

The data of the current study are available from the corresponding author on reasonable request.

\section{Declarations}

\section{Ethics approval and consent to participate}

The study was approved by the Research Ethics Committee of the Faculty of Medicine, King Abdulaziz University with reference number 176-16. Filling the survey questionnaire implied the participants' consent to be included in the study. The confidentiality of all the participants was maintained throughout the study.

\section{Competing interests}

The authors declare that they have no competing interests.

\section{References}

1. Chui TB, bin Ahmad MS. Evaluation of service quality of private higher education using service improvement matrix. Procedia-Soc Behav Sci. 2016;224:132-40. http://dx.doi.org/10.1016/j.sbspro.2016.05.417

2. Heck RH, Johnsrud LK, Rosser VJ. Administrative effectiveness in higher education: Improving assessment procedures. Res Higher Educ. 2000;41(6):663-84. http://dx.doi.org/10.1023/A:1007096803784

3. Tan KC, Kek SW. Service quality in higher education using an enhanced SERVQUAL approach. Qual Higher Educ. 2004;10(1):17-24. http://dx.doi.org/10.1080/1353832242000195032

4. Kitcharoen $\mathrm{K}$. The importance-performance analysis of service quality in administrative departments of private universities in Thailand. ABAC J. 2004;24(3).

5. Shurair AS, Pokharel S. Stakeholder's perception of service quality: a case in Qatar. Qual Assur Educ. 2019;27(4):493-510. https://doi.org/10.1108/qae-05-2017-0023

6. Arambewela R, Hall J. A comparative analysis of international education satisfaction using SERVQUAL. J Serv Res. 2006;6(Special):141-63. http://dx.doi.org/10.1016/j.sbspro.2014.01.350

7. Ruiqi Z, Adrian P. Using SERVQUAL to measure the service quality of travel agents in Guangzhou, South China. J Serv Res. 2009;9(1):57-107.

8. Huang WH. The impact of other-customer failure on service satisfaction. Int J Serv Industry Manage. 2008;19(4):521-36. http://dx.doi.org/10.1108/09564230810891941 
9. Saleh F, Ryan C. Analysing service quality in the hospitality industry using the SERVQUAL model. Serv Industries J. 1991;11(3):324-45. http://dx.doi.org/10.1080/02642069100000049

10. Kwan W, Hee TJ. Measuring service quality in Singapore retail banking: a gap analysis and segmentation approach. Singapore Manage Rev. 1994;16(2):1-24.

11. Ozretić Došen $Đ$, Škare $V$, Čerfalvi V, Benceković Ž, Komarac T. Assessment of the quality of public hospital healthcare services by using SERVQUAL. Acta Clinica Croatica. 2020;59(2):285-92. http://dx.doi.org/10.20471/acc.2020.59.02.12

12. Alnsour MS, Tayeh BA, Alzyadat MA. Using SERVQUAL to assess the quality of service provided by Jordanian telecommunications Sector. Int J Commerce Manage. 2014;24(3):209-19. http://dx.doi.org/10.1108/IJCoMA-03-2012-0021

13. Puri G, Singh D. The role of service quality and customer satisfaction in tourism industry: A review of SERVQUAL Model. Int J Res Analytical Rev. 2018;5(4):745-51.

14. Rigotti S, Pitt L. SERVQUAL as a measuring instrument for service provider gaps in business schools. Manage Res News. 1992;15(3):9-17. https://doi.org/10.1108/eb028197

15. Asogwa BE, Asadu BU, Ezema JU, Ugwuanyi FC. Use of ServQUAL in the evaluation of service quality of academic libraries in developing countries. Lib Philosophy Practice. 2014;21:2019.

16. Gholami A, Gazerani A, Behfar K, Asghari A, Mohammadzadeh H, Samadi A, Foroozanfar Z. Quality evaluation of educational services gap in Neyshabur Faculty of Medical Sciences based on service quality scale. Shiraz E-Med J. 2014;15(3);e21869. https://dx.doi.org/10.17795/semj21869

17. De Oliveira OJ, Ferreira EC. Adaptation and application of the SERVQUAL scale in higher education. In: Proceedings of POMS 20th Annual Conference Orlando, Florida USA 2009 (pp. 1-20).

18. Parasuraman A, Zeithaml VA, Berry LL. A conceptual model of service quality and its implications for future research. J Marketing. 1985;49(4):41-50. http://dx.doi.org/10.2307/1251430

19. Parasuraman A, ZeithamI VA, Berry L. SERVQUAL: A multiple-item scale for measuring consumer perceptions of service quality. J Retailing. 1988;16(1):12-37.

20. Andayesh M, Nasab MB, Shahi S. The Evaluation of Students' Satisfaction with Educational Services Quality in Islamic Azad University of Dezful Based on SERVPERF Model. Int J New Trends Educ Literature. 2014;1:11-9.

21. Bahadori M, Mousavi SM, Sadeghifar J, Haghi M. Reliability and performance of SERVQUAL survey in evaluating quality of medical education services. Int J Hospital Res. 2013;2(1):39-44.

22. Anderson EA. Measuring service quality at a university health clinic. Int J Health Care Qual Assur. 1995;8(2):32-7. https://doi.org/10.1108/09526869510081866

23. Cook C, Thompson B. Higher-order factor analytic perspectives on users' perceptions of library service quality. Library Info Sci Res. 2000;22(4):393-404. https://doi.org/10.1016/S0740-8188(00)00052-9

24. Browne BA, Kaldenberg DO, Browne WG, Brown DJ. Student as customer: Factors affecting satisfaction and assessments of institutional quality. J Marketing Higher Educ. 1998;8(3):1-4. https://doi.org/10.1300/J050v08n03_01

25. Guolla M. Assessing the teaching quality to student satisfaction relationship: Applied customer satisfaction research in the classroom. J Marketing Theory Practice. 1999;7(3):87-97.

https://doi.org/10.1080/10696679.1999.11501843

Page $15 / 18$ 
26. Alves $\mathrm{H}$, Raposo M. The influence of university image on student behaviour. Int J Educ Manage. 2010;24(1):73-85. http://dx.doi.org/10.1108/09513541011013060

27. Marzo-Navarro M, Pedraja-Iglesias M, Rivera-Torres MP. Measuring customer satisfaction in summer courses. Qual Assur Educ. 2005;13(1):53-65. http://dx.doi.org/10.1108/09684880510578650

28. Aldridge S, Rowley J. Conducting a withdrawal survey. Qual Higher Educ. 2001;7(1):55-63. http://dx.doi.org/10.1080/13538320120045085

29. Hasan HF, Ilias A, Rahman RA, Razak MZ. Service quality and student satisfaction: A case study at private higher education institutions. Int Business Res. 2008;1(3):163-75. https://doi.org/10.5539/ibr.v1n3p163

30. Kanji GK, Tambi AM, Wallace W. A comparative study of quality practices in higher education institutions in the US and Malaysia. Total Qual Manage. 1999;10(3):357-71. https://doi.org/10.1080/0954412997884

31. Gregory JL. Applying SERVQUAL: Using service quality perceptions to improve student satisfaction and program image. J Applied Res Higher Educ. 2019;11(4):788-99. http://dx.doi.org/10.1108/JARHE-12-20180268

32. Kassim NM, Bogari N, Zain M. Service quality of a public university in Saudi Arabia. J e-Learn Higher Educ. 2013:1-18. http://dx.doi.org/10.5171/2013.954273

33. Tausif MR. Assessing the quality of education in Saudi Arabia. Int J Econ Res. 2017;14(17):521-8.

34. Al-Otaibi SA, Yusof SM, Ismail WK. Service Quality and Student Satisfaction in Higher Education Institutions in Saudi Arabia. Int J Manage. 2020;11(7):648-65. https://doi.org/10.34218/IJM.11.7.2020.058

35. Aldarmahi A, Algahtani H, Alrabia M, Abuarab N, Shirah B. Determination of quality gap for educational services in undergraduate medical education: A cross-sectional study in Saudi Specialized Health Sciences University. Saudi Med J. 2019;40(6):595-600. https://dx.doi.org/10.15537\%2Fsmj.2019.6.24189

36. Kebriaei A, Akbari F. Quality gap of educational services at Zahedan University of Medical Sciences, Iran. Bangladesh Med Res Counc Bull. 2008;34(3):76-80. https://doi.org/10.3329/bmrcb.v34i3.1646

37. Aghamolaei T, Zare S. Quality gap of educational services in viewpoints of students in Hormozgan University of medical sciences. BMC Med Educ. 2008;8(1):1-6. https://doi.org/10.1186/1472-6920-8-34

38. Legčević J. Quality gap of educational services in viewpoints of students. Ekonomska Misao i Praksa. 2009(2):279-98.

39. Ruby CA. Assessing satisfaction with selected student services using SERVQUAL, a market-driven model of service quality. NASPA J. 1998;35(4):331-41. https:// doi.org/10.2202/1949-6605.1059

40. Yousapronpaiboon K. SERVQUAL: Measuring higher education service quality in Thailand. Procedia-Soc Behav Sci. 2014;116:1088-95. http://dx.doi.org/10.1016/j.sbspro.2014.01.350

41. Ansary A, Jayashree S, Malarvizhi CA. The effect of gender and nationality on service quality in Malaysian higher education. J Devel Areas. 2014:97-118. http://dx.doi.org/10.1353/jda.2014.0076

42. Ham L, Hayduk S. Gaining competitive advantages in higher education: analyzing the gap between expectations and perceptions of service quality. Int J Value-Based Manage. 2003;16(3):223-42. https://doi.org/10.1023/A:1025882025665

43. Ilias A, Hasan HF, Rahman RA, Yasoa MR. Student satisfaction and service quality: Any differences in demographic factors. Int Business Res. 2008;1(4):131-43. http://dx.doi.org/10.5539/ibr.v1n4p131

44. Soutar G, McNeil M. Measuring service quality in a tertiary institution. J Educ Admin. 1996;34(1):72-82. https://doi.org/10.1108/09578239610107174

Page $16 / 18$ 
45. Abu Rashed Osman D, Sarkar JB, Islam EM. Revisiting Student Satisfaction Through SERVQUAL: Private Tertiary Education Perspective. British J Edu. 2017;5(11):119-37.

46. Yusoff M, McLeay F, Woodruffe-Burton $\mathrm{H}$. Dimensions driving business student satisfaction in higher education. Qual Assur Educ. 2015;23(1):86-104. https://doi.org/10.1108/QAE-08-2013-0035

\section{Figures}

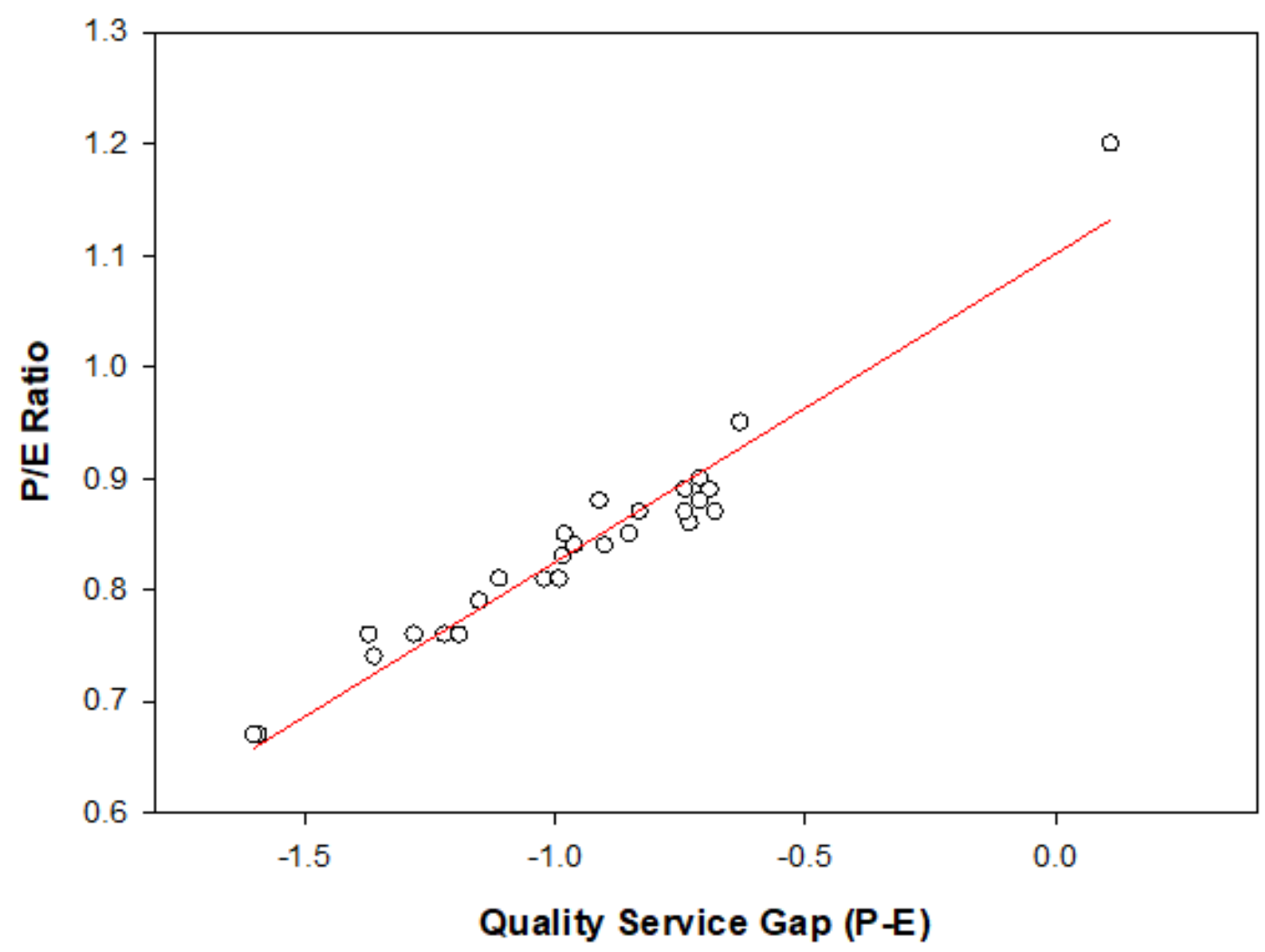

\section{Figure 1}

Correlation between service quality gap $(P-E)$ and $P / E$ ratio for 27 items. Linear line represents linear regression fitting with equation $P / E=0.2768 G a p+1.1021$, R2 0.9412. 


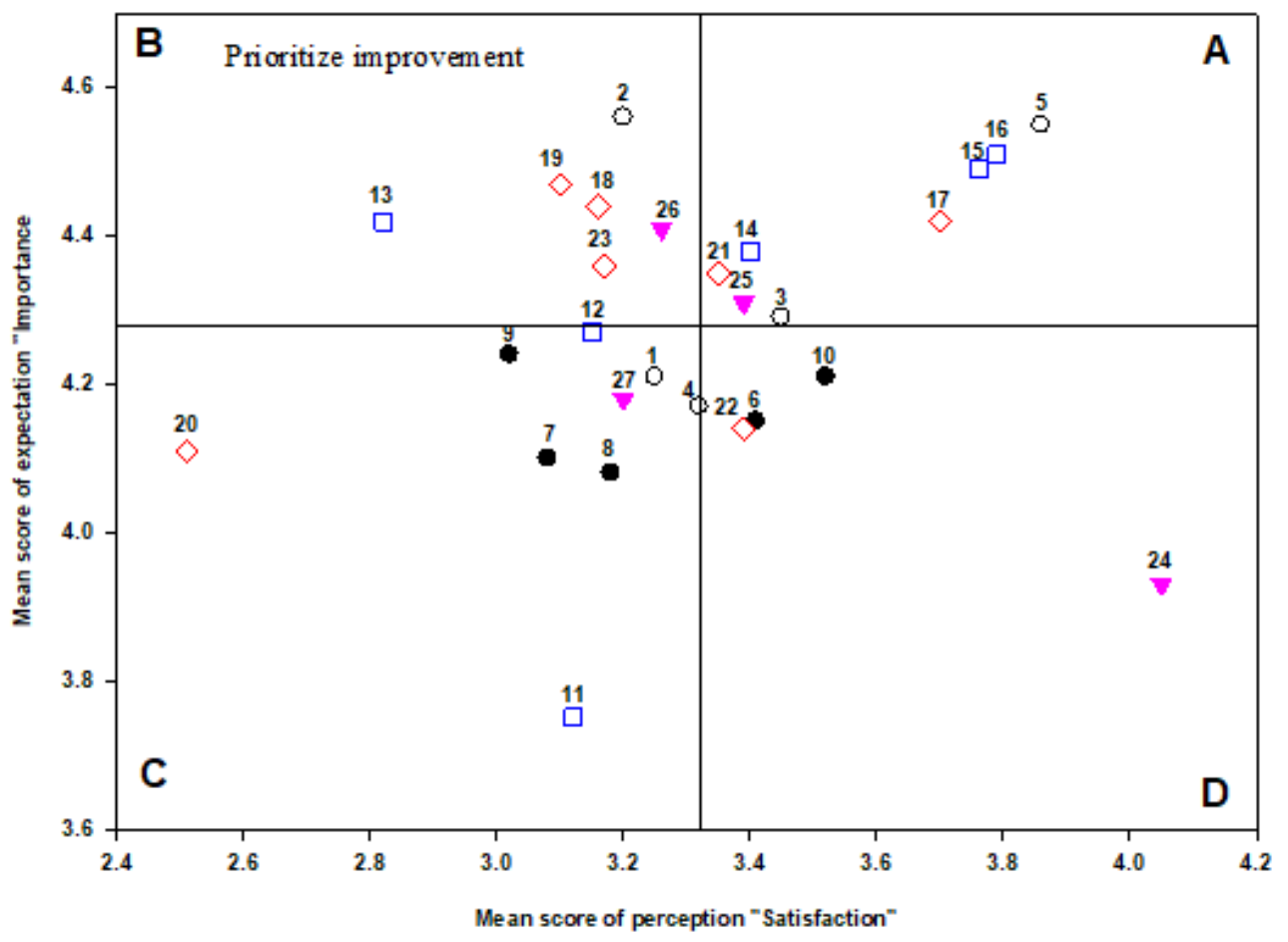

$\circ$, Assurance; •, Responsiveness, $\square$, Empathy; $\diamond$, Reliability; $\nabla$, Tangibles

Figure 2

Developed service improvement matrix. The graph was divided into four quadrants using overall mean of perception (3.32) and overall mean score of expectation (4.28). 